COMUNICAÇÃO CIENTÍFICA

\title{
LIMPEZA CLONAL DE MUDAS DE VIDEIRA INFECTADAS POR Xanthomonas campestris pv. viticola ${ }^{1}$
}

\author{
ADRIANO MÁRCIO FREIRE SILVA², NATONIEL FRANKLIN DE MELO ${ }^{3}$, \\ ELINEIDE BARBOSA DE SOUZA ${ }^{4}$, ÂNGELA KATIUSIA COELHO ${ }^{5}$, \\ ROSA DE LIMA RAMOS MARIANO 6
}

RESUMO - O cancro bacteriano da videira é causado por Xanthomonas campestris pv. viticola (Xcv). Visando à limpeza clonal de mudas de 'Red Globe', foram estudados: tamanho ideal de ápices e gemas axilares para cultivo em meio de Galzy modificado (MGM); efeito da termoterapia $\left(38^{\circ} \mathrm{C} / 30\right.$ dias); e ação de antibióticos na eliminação de Xcv em videiras infectadas. Os percentuais de contaminação por Xcv e de regeneração foram analisados, e as plantas obtidas foram indexadas em meio ágar nutritivo-dextrose-extrato de levedura-ampicilina (NYDAM), seguindo-se teste de patogenicidade. O cultivo de explantes com $3 \mathrm{~mm}$ possibilitou a obtenção de plantas livres da bactéria, com regeneração 14,3 vezes maior que explantes com $1 \mathrm{~mm}$. A termoterapia de mudas infectadas, associada ao cultivo in vitro, não eliminou o patógeno. $\mathrm{O}$ cultivo de explantes com $10 \mathrm{~mm}$, durante 40 dias em MGM + cefotaxima ( $300 \mathrm{mg} \mathrm{L}^{-1}$ ), proporcionou limpeza clonal das mudas. A indexação de plantas de videira regeneradas in vitro, quanto à infecção por Xcv utilizando NYDAM, seguida de teste de patogenicidade, é uma alternativa econômica e eficiente para produção de mudas de alta qualidade fitossanitária.

Termos para Indexação: Vitis vinifera, cultivo in vitro, fitobacteriologia, Xanthomonas campestris pv. viticola.

\section{CLONAL CLEANING OF GRAPEVINE PLANTS INFECTED BY Xanthomonas campestris pv. viticola}

\begin{abstract}
Bacterial canker is caused by Xanthomonas campestris pv. viticola (Xcv). In order to eliminate Xcv from 'Red Globe' plants it was studied: optimal size of meristem tips and axillary buds for cultivation in modified Galzy's medium (MGM); effects of thermotherapy $\left(38^{\circ} \mathrm{C} / 30\right.$ days); and action of antibiotics in the elimination of Xcv in infected grapevines. The percentages of contamination by Xcv and regeneration were analyzed and plants obtained were indexed using the semi-selective culture medium nutrient agar-dextrose-yeast extract-ampicilin (NYDAM) followed by a pathogenicity test. The cultivation of $3 \mathrm{~mm}$ explants permitted to obtain plants free of bacteria with regeneration 14.3 times higher than 1 $\mathrm{mm}$ explants. The thermotherapy of infected plants associated to the in vitro culture did not eliminate the pathogen. The cultivation of $10 \mathrm{~mm}$ explants during 40 days in MGM + cefotaxime $\left(300 \mathrm{mg} \mathrm{L}^{-1}\right)$ eliminated $\mathrm{Xcv}$ from grapevine plants. The indexation of micropropagated grapevine plants for Xcv infection by using NYDAM medium followed by a pathogenicity test is an economical and efficient alternative to produce plants of high sanity quality.
\end{abstract}

Index terms: Vitis vinifera, in vitro culture, phytobacteriology, Xanthomonas campestris pv. viticola

\footnotetext{
1(Trabalho 199-12). Recebido em: 22-06-2012. Aceito para publicação em: 29-11-2012.

${ }^{2}$ Eng. Agr., Dr. Departamento de Agronomia, Universidade Federal Rural de Pernambuco, Av. Dom Manoel de Medeiros, s/n, Dois Irmãos, Recife, PE. CEP: 52171-900. E-mail: adrianomfsilva@yahoo.com.br

${ }^{3}$ Biólogo, Dr. Embrapa Semi Árido, BR 428, Km 152, Zona Rural - Caixa Postal 23, Petrolina, PE. CEP 56302-970. E-mail: natoniel@ embrapa.cpatsa.br

${ }^{4}$ Eng. Agr., Prof. Dra. Departamento de Microbiologia, Universidade Federal Rural de Pernambuco, Av. Dom Manoel de Medeiros, s/n, Dois Irmãos, Recife, PE. CEP: 52171-900. E-mail: elineidebs@yahoo.com.br

${ }^{5}$ Técnica em Química, Embrapa Semiárido, BR 428, Km 152, Zona Rural - Caixa Postal 23, Petrolina, PE. CEP 56302-970. E-mail: angela@embrapa.cpatsa.br

${ }^{6}$ Eng. Agr., Prof. Dra. Departamento de Agronomia, Universidade Federal Rural de Pernambuco, Av. Dom Manoel de Medeiros, s/n, Dois Irmãos, Recife, PE. CEP: 52171-900. E-mail: rrmbac@gmail.com
} 
Em 1998, o cancro bacteriano da videira, causado por Xanthomonas campestris pv. viticola (Nayudu) Dye (Xcv), foi detectado pela primeira vez no Brasil, em parreirais da região do Vale do Submédio São Francisco (LIMA et al., 1999). Nessa região, foi observada alta incidência da doença e redução considerável de produção em áreas de 'Red Globe'e 'Festival', sendo também detectado o cancro bacteriano em parreirais recém-instalados, indicando a presença do patógeno no material propagativo.

$\mathrm{Na}$ ausência de um produto químico capaz de erradicar eficientemente vírus e bactérias de plantas infectadas, técnicas de cultura de tecidos vêm sendo utilizadas, dentre as quais o cultivo in vitro de ápices e meristemas (BARLASS, 1987). A associação entre cultivo de tecidos meristemáticos e termoterapia, quimioterapia ou ambas, pode aumentar significativamente as chances de sucesso do método (PANATTONI et al., 2007).

A indexação de matrizes micropropagadas é imprescindível para a obtenção de mudas livres de patógenos, sendo uma das melhores formas para controlar fitobacterioses. Apesar da importância da indexação de mudas de videira para o manejo do cancro bacteriano, não foram encontrados na literatura disponível trabalhos sobre este tema, no Brasil e no mundo. Portanto, este trabalho visou à limpeza clonal de mudas de videira 'Red Globe', buscando selecionar o tamanho ideal de ápices e gemas axilares para cultivo in vitro; verificar o efeito da termoterapia na erradicação de Xcv de mudas infectadas; e testar antibióticos para eliminar o patógeno em explantes oriundos de videiras infectadas.

Mudas da cv. Red Globe com cinco pares de folhas, produzidas na Estação Experimental de Bebedouro da Embrapa Semiárido, foram submetidas a duas pulverizações semanais com o fungicida Iprodione $\left(1 \mathrm{~mL} \mathrm{~L}^{-1}\right)$, sendo mantidas durante 20 dias em casa de vegetação. Três dias após a última pulverização, as mudas foram inoculadas com o isolado Xcv3, pela técnica da picada com agulha em internódios do ramo principal. Os ferimentos foram cobertos com algodão umedecido e envolvidos por papel-alumínio, sendo as mudas mantidas por $72 \mathrm{~h}$, em casa de vegetação a $27 \pm 2^{\circ} \mathrm{C}$.

Após o surgimento dos sintomas da doença, ápices caulinares e as três primeiras gemas axilares foram retirados das mudas e desinfestados em solução de álcool a 70\%, durante $1 \mathrm{~min}$, hipoclorito de sódio a $2 \%$, durante $20 \mathrm{~min}$, seguindo-se três lavagens em água destilada e esterilizada (ADE). Os explantes foram cortados e reduzidos para 10; 3 e $1 \mathrm{~mm}$ de comprimento e introduzidos em tubos de ensaio $(17 \times 2 \mathrm{~cm})$ contendo meio de Galzy (1964), modificado (MGM) pela adição de ácido indolacético (AIA) $0,1 \mathrm{mg} \mathrm{L}^{-1}$, com o pH ajustado a 5,9, antes da autoclavagem. Os tubos de ensaio foram incubados em sala de crescimento com fotoperíodo de $16 \mathrm{~h}$ de luz, temperatura de $25^{\circ} \mathrm{C}$ e intensidade luminosa de $40 \mu \mathrm{mol} \mathrm{m}{ }^{-2}$.

O percentual de contaminação dos explantes por Xcv foi avaliado 21 dias após a incubação e, em caso de crescimento bacteriano sobre o explante, foi realizada repicagem para o meio semisseletivo NYDAM (NYDA + ampicilina $0,1 \mathrm{~g} \mathrm{~L}^{-1}$ ) (PEIXOTO et al., 2006), seguindo-se teste de patogenicidade em mudas da cv. Red Globe.

O percentual de regeneração foi avaliado após 120 dias, e todos os clones obtidos de plantas que não apresentaram contaminação in vitro, foram indexados. Segmentos nodais $(1 \mathrm{~cm}$ de comprimento da região mediana do caule principal) foram colocados em microtubos tipo Eppendorf contendo $100 \mu \mathrm{L}$ de ADE, macerados e plaqueados em NYDAM, incubando-se a $28^{\circ} \mathrm{C}$, durante 48 a $72 \mathrm{~h}$. Colônias típicas de Xcv foram repicadas e inoculadas em mudas da cv. Red Globe. O delineamento estatístico utilizado foi o inteiramente casualizado, com três tratamentos e quatro repetições, sendo cada repetição constituída por cinco tubos de ensaio contendo os explantes.

Para verificar o efeito da termoterapia na eliminação de Xcv em mudas de videira infectadas, quatro plantas inoculadas foram mantidas em casa de vegetação a $27 \pm 2^{\circ} \mathrm{C}$ e quatro foram colocadas em câmara de termoterapia por 30 dias a $38^{\circ} \mathrm{C}$. Após o surgimento dos sintomas, ápices caulinares de $3 \mathrm{~mm}$ de comprimento e as três primeiras gemas axilares foram retirados das mudas e processados de maneira similar àquela descrita para a determinação do tamanho mínimo do explante. O percentual de contaminação por Xcv foi avaliado após 21 dias, e o percentual de regeneração e a indexação das plantas, após 70 dias de cultivo, conforme descrito anteriormente. $\mathrm{O}$ delineamento estatístico utilizado foi o inteiramente casualizado, com dois tratamentos e quatro repetições, sendo cada repetição constituída por quatro tubos de ensaio contendo os explantes.

Visando a avaliar o efeito de diferentes antibióticos na eliminação de Xcv, mudas com sintomas de cancro bacteriano foram obtidas por inoculação, e a coleta de explantes, a desinfestação e a incubação dos tubos na sala de crescimento foram realizadas como já descrito. Explantes com $10 \mathrm{~mm}$ de comprimento foram introduzidos ao meio de cultura MGM adicionados separadamente dos antibióticos: tetraciclina $\left(300 \mathrm{mg} \mathrm{L}^{-1}\right)$, cefotaxima (300 $\mathrm{mg} \mathrm{L}^{-1}$ ), cloranfenicol (300 $\mathrm{mg} \mathrm{L}^{-1}$ ), ácido nalidíxico (300 $\left.\mathrm{mg} \mathrm{L}^{-1}\right)$, eritromicina $\left(150 \mathrm{mg} \mathrm{L}^{-1}\right)$ 
e estreptomicina $\left(100 \mathrm{mg} \mathrm{L}^{-1}\right)$, selecionados em antibiograma para Xcv por Peixoto et al. (2006).

Os percentuais de contaminação por Xcv e de regeneração foram avaliados após 40 dias de cultivo em meio MGM + antibiótico. Todos os explantes que regeneraram, ou não, mas que não apresentavam visualmente contaminação bacteriana, foram transferidos para o meio MGM sem antibiótico. Após 45 dias, novos percentuais de contaminação por Xcv e de regeneração foram observados, e as plantas obtidas foram indexadas. O delineamento estatístico utilizado foi o inteiramente casualizado, com sete tratamentos e quatro repetições, sendo cada repetição constituída por quatro tubos de ensaio.

Os explantes com $1 \mathrm{~mm}$ apresentaram percentual de contaminação por Xcv (15\%) significativamente menor $(\mathrm{P} \leq 0,05)$ que os demais. Explantes com 3 e 10 mm diferiram entre si, com percentuais de contaminação de 50 e $100 \%$, respectivamente. O teste de $\chi^{2}$ evidenciou que explantes com $1 \mathrm{~mm}$ apresentaram regeneração $(26 \%)$ significativamente menor $(\mathrm{P} \leq 0,01)$ que aqueles com $3 \mathrm{~mm}(90 \%)$. Explantes com $10 \mathrm{~mm}$ não regeneraram, pois apresentaram contaminação. O teste de razão de chances mostrou que a possibilidade de os explantes com $3 \mathrm{~mm}$ regenerarem é 14,3 vezes maior que a dos explantes com $1 \mathrm{~mm}$. O tempo total de regeneração de novas plantas foi de 120 dias para explantes com $1 \mathrm{~mm}$ e de 70 dias para explantes com $3 \mathrm{~mm}$.

Em geral, a percentagem de plantas obtidas mediante a cultura de ápices caulinares é baixa devido a fatores como infecção de microrganismos, ressecamento, oxidação, meio de cultivo inadequado, além do fenômeno de dormência. Por outro lado, Gribaudo et al. (2007) verificaram que o cultivo in vitro de gemas axilares foi suficiente para obtenção de grande quantidade de plantas de videira cvs. Barbera e Chardonnay livres de fitoplasmas associados a "flavescence dorée" e "bois noir", após 6 a 9 meses de cultivo.

Com relação ao explante, quanto menor o tamanho, maiores são as chances de obter material propagativo livre de patógenos, sendo menor a capacidade organogênica. Desta forma, ápices caulinares de mandioca com menos de $0,2 \mathrm{~mm}$, livres de vírus, somente formaram calo ou raízes; entre 0,2 e 0,8 $\mathrm{mm}, 90$ a 95\% desses ápices caulinares regeneraram plantas livres do patógeno; mas plantas regeneradas de explantes com 0,9 e $1 \mathrm{~mm}$ apresentaram sintomas de virose (KARTA; GAMBORG, 1975).

No presente estudo, ao contrário do esperado, explantes provenientes de mudas submetidas à termoterapia apresentaram percentual de contaminação por Xcv significativamente maior $(93,0 \%)$ em com- paração às mudas não tratadas e mantidas em casa de vegetação $(43,7 \%)$. O percentual de regeneração de explantes obtidos de mudas não tratadas foi de $77,7 \%$, enquanto o de mudas tratadas foi zero. A total ineficiência da termoterapia pode estar associada à utilização de uma temperatura $\left(38^{\circ} \mathrm{C}\right)$ incapaz de erradicar ou paralisar a colonização do patógeno. Dentro da planta, a bactéria está protegida, podendo, possivelmente, suportar temperaturas mais altas. Por outro lado, não se pode descartar a possibilidade de as condições de incubação terem favorecido o patógeno, visto que a câmara de termoterapia é um sistema fechado e que, para a manutenção das mudas vivas, é necessário irrigá-las, elevando a umidade relativa do ambiente. Tais condições são extremamente favoráveis para a proliferação de bactérias, o que foi comprovado pela observação do aparecimento de novos cancros nas mudas durante o tratamento termoterápico. No entanto, a associação do calor seco $\left(47-48^{\circ} \mathrm{C}\right)$ com termoterapia de plântulas $\left(37^{\circ} \mathrm{C}\right)$ e cultura de ápices e meristemas erradicou $X$. campestris pv. phaseoli e Pseudomonas syringae pv. phaseolicola de sementes de feijoeiro (GRUM et al., 1998).

No experimento com antibióticos, após 40 dias, os tratamentos com cefotaxima, tetraciclina e cloranfenicol não apresentaram contaminação por $\mathrm{Xcv}$, diferindo de eritromicina, estreptomicina e ácido nalidíxico que apresentaram $100 \%$ de contaminação, similarmente à testemunha. A eficiência de cefotaxima, tetraciclina e cloranfenicol na eliminação de bactérias, em plantas cultivadas in vitro, também foi obtida por Barrett e Cassells (1994) e Rodrigues (2005). Resultados contrastantes foram obtidos por Peixoto et al. (2006) para os antibióticos eritromicina, estreptomicina e ácido nalidíxico.

Apesar de cefotaxima, tetraciclina e cloranfenicol terem controlado totalmente o aparecimento de bactérias no meio de cultura, os dois últimos antibióticos impediram a regeneração dos explantes. No entanto, no tratamento com $300 \mathrm{mg} \mathrm{L}^{-1}$ de cefotaxima, $68,75 \%$ dos explantes, mesmo apresentando algumas folhas malformadas, foram capazes de regenerar no meio com antibiótico e, após cultivo por 45 dias em meio sem antibiótico, formaram plantas normais. Recuperação similar também foi observada em cana-de-açúcar cultivada em meio com oxitetraciclina (500 $\mathrm{mg} \mathrm{L}^{-1}$ ) (WONGKAEW; FLETCHER, 2004).

Em todos os experimentos, a bactéria presente nos explantes foi capaz de crescer no meio NYDAM, com colônias brancas, aspecto viscoso e capacidade de causar sintomas típicos do cancro bacteriano. Por outro lado, todos os explantes que não apresentaram contaminação foram capazes de formar novas plan- 
tas, as quais foram negativas no teste de indexação. Portanto, nas atuais circunstâncias, a indexação de plantas regeneradas in vitro através da utilização do meio semisseletivo NYDAM, seguido de teste de patogenicidade, é uma alternativa econômica e eficiente para a seleção de mudas de videira livres de Xcv.

A utilização de segmentos nodais para a multiplicação dos clones proporcionou a obtenção de quatro novas plantas a cada 60 dias. Após a fase de multiplicação, as plantas foram aclimatadas, verificando-se $58 \%$ de sobrevivência. Essas plantas foram avaliadas mensalmente para sintomas de cancro bacteriano e, após oito meses, nenhuma apresentou sintomas.

O emprego de técnicas de cultura de tecidos possibilitou a obtenção de mudas de videira livres de Xcv. Portanto, a implementação de um programa de multiplicação e distribuição de mudas micropropagadas sadias poderá suprir as demandas de viveiristas e pesquisadores.

\section{REFERÊNCIAS}

BARLASS, M. Elimination of stem pitting and corky bark diseases from grapevine by fragmented shoot apex culture. Annals of Applied Biology, Warwick, v.110, n.3, p.653-656, 1987.

BARRETT, C.; CASSELLS, A. C. An evaluation of antibiotics for the elimination of Xanthomonas campestris pv. pelargonii (Brown) from Pelargonium $\mathrm{x}$ domesticum cv. 'Grand Slam' explants in vitro. Plant Cell, Tissue and Organ Culture, Dordrecht, v.36, n.2, p.169-175, 1994.

GALZY, R. Technique de thermotherápie des viruses de las vigni. Annales des Epiphyties, Paris, v.15, n.1, p.245-256, 1964.

GRIBAUDO, I.; RUFFA, P.; CUOZZO, D.; GAMBINO, G.; MARZACHI, C. Attempts to eliminate phytoplasmas from grapevine clones by tissue culture techniques. Bulletin of Insectology, Bologna, v.60, n.2, p.315-316, 2007.

GRUM. M.; CAMLOH. M.; RUDOLPH. K.; RAVNIKAR. M. Elimination of bean seed-borne bacteria by thermotherapy and meristem culture. Plant Cell, Tissue and Organ Culture, Dordrecht, v.52, n.1, p.79-82, 1998.
KARTA, K. K.; GAMBORG, O. L. Elimination of cassava mosaic disease by meristem culture. Phytopathology, Saint Paul, v.65, n.7, p.826-828, 1975.

LIMA, M. F.; FERREIRA, M. A. S. V.; MOREIRA, W. A; DIANESE, J. C. Bacterial canker of grapevine in Brazil. Fitopatologia Brasileira, Brasília, v.24, n.3, p.440-443, 1999.

PANATTONI, A.; D'ANNA, F.; CRISTANE, C.; TRIOLO, E. Grapevine vitivirus A eradication in Vitis vinifera explants by antiviral drugs and thermotherapy. Journal of Virological Methods, Amsterdam, v.146, n.1, p.129-135, 2007.

PEIXOTO, A. R.; MARIANO, R. L. R.; VIANA, I. O. Meio semi-seletivo para isolamento de Xanthomonas campestris pv. viticola. Ciência Rural, Santa Maria, v.36, n.4, p.1317-1320, 2006.

RODRIGUES, P. H. V. In vitro establishment of Heliconia rauliniana. Scientia Agricola, Piracicaba, v.62, n.1, p.69-71, 2005.

WONGKAEW, P.; FLETCHER, J. Sugarcane white leaf phytoplasma in tissue culture: long-term maintenance, transmission, and oxytetracycline remission. Plant Cell Reports, Berlin, v.23, n.6, p.426-434, 2004. 